\title{
Reactive Black 5 (RB5): Pengolahan Air Limbah Tekstil dengan Adsorbsi Menggunakan Powdered Karbon Aktif
}

\section{Reactive Black 5 (RB5): Treatment of Textile Wastewater by Adsorption Using Powdered Activated Carbon}

\author{
IVA YENIS SEPTIARIVA ${ }^{1}$, I WAYAN KOKO SURYAWAN ${ }^{2 *}$, ARIYANTI SARWONO² \\ ${ }^{1}$ Study Program of Civil Engineering, Faculty of Engineering, Universitas Sebelas Maret, JI. Ir. Sutami 36A Surakarta 57126, \\ Indonesia \\ ${ }^{2}$ Faculty of Infrastructure Planning, Department of Environmental Engineering, Universitas Pertamina, Komplek Universitas \\ Pertamina \\ *Email: i.suryawan@universitaspertamina.ac.id
}

\begin{abstract}
ABSTRAK
Umumnya, industri tekstil menggunakan berbagai pewarna sintetis yang menghasilkan air limbah yang sangat berwarna. Oleh karena itu, air limbah tekstil ini harus diolah sebelum dibuang ke lingkungan. Penelitian ini bertujuan untuk mengetahui penyisihan warna dengan teknik adsorpsi menggunakan karbon aktif. Metode ini dianggap sebagai teknologi berbiaya rendah dan perawatan yang mudah untuk pengolahan air limbah. Proses adsorpsi batch dilakukan dengan waktu kontak yang berbeda yaitu 5-60 menit dan variasi konsentrasi awal yang mengandung Reactive Black 5 (RB-5) sebesar $5 \mathrm{mg} / \mathrm{L}$; $10 \mathrm{mg} / \mathrm{L}$; $15 \mathrm{mg} / \mathrm{L}$; dan $20 \mathrm{mg} / \mathrm{L}$. Azo-Reactive Black-5 adalah material pewarna yang digunakan untuk membuat air limbah artifisial. Hasil penelitian menunjukkan bahwa proses adsorpsi menurunkan kadar konsentrasi warna masing-masing sebesar 86,21\%, 85,21\%, 84,29\%, dan 71,07\% selama 60 menit. Peningkatan konsentrasi zat warna dalam air limbah menyebabkan efisiensi penghilangan warna yang rendah. Selain itu, penelitian mengevaluasi efektivitas adsorpsi batch oleh karbon aktif karena efisiensi penghilangan warna dapat mencapai lebih dari 50\% setelah waktu kontak 30 menit. Hal ini terlihat pada konsentrasi awal $5 \mathrm{mg} / \mathrm{L}$ dan $20 \mathrm{mg} / \mathrm{L}$ dengan efisiensi penyisihan sebesar 66,18\% dan 53,97\%. Kinetika adsorpsi yang sesuai untuk pendekatan pemodelan pada penelitian ini adalah Langmuir isotherm dengan nilai $r^{2}$ yang lebih besar dan mendekati nilai 1 yaitu 0,9756. Estimasi kapasitas adsorpsi maksimum yang diperoleh dari model sebesar 4,353 mg/g.
\end{abstract}

Kata kunci: air limbah tekstil, warna, adsorpsi, efisiensi penyisihan

\begin{abstract}
Generally, the textile industry uses various synthetic dyes that produced a large amount of highly colored wastewater. This research aims to investigate the color removal by adsorption using powdered activated carbon. This method is considered viable due to cost effective and ease of maintenance for wastewater treatment. The batch adsorption process was carried out at different contact times of 5-60 minutes and varied initial dye concentration containing azo-Reactive Black 5 (RB-5) of $5 \mathrm{mg} / \mathrm{L} ; 10 \mathrm{mg} / \mathrm{L} ; 15 \mathrm{mg} / \mathrm{L}$; and $20 \mathrm{mg} / \mathrm{L}$. A synthetic RB-5 was prepared as the artificial wastewater to simulate the actual wastewater. The adsorption proceeded initially with higher rates and gradually slowed down until reached a constant value due to the carbon surface's saturation with increasing contact time. The results showed that, at different initial dye concentration, the adsorption process decreased color concentration for 60 minutes by $86.21 \%, 85.21 \%, 84.29 \%$, and $71.07 \%$ respectively. The increase of initial dye concentration lowers color removal efficiency. Besides, the effectiveness of adsorption by activated carbon was found more than $50 \%$ after 30 minute of contact time. The efficiency removal presented initial concentration of $5 \mathrm{mg} /$ and $20 \mathrm{mg} / \mathrm{L}$ was $66.18 \%$ and $53.97 \%$, respectively. Langmuir and Freundlich isotherm were also plotted to assess the kinetics of adsorption. Langmuir isotherm gave the best modelling approach for adsorption kinetics as indicated by higher coefficient of determination $\left(\mathrm{r}^{2}\right)$ of 0.9756 . An estimated maximum adsorption capacity obtained from the model was $4.353 \mathrm{mg} / \mathrm{g}$.
\end{abstract}

Keywords: textile wastewater, color, adsorption, removal efficiency, 


\section{INTRODUCTION}

\subsection{Research Background}

Reactive Black 5 (RB5) dye is one of the most commonly used dyes in the textile industry. This dyeing process generates wastewater, therefore the textile wastewater must be treated before being discharged into the environment. This textile wastewater is heavily used through all processing operations such as desiring, scouring, dyeing, and printing(1). These effluents contain chemicals like organic, dye, metals, and nutrients ${ }^{(2)}$. Textiles mills consume about $200 \mathrm{~L}$ per kilogram of fabric processed per day, hence the discharged wastewater highly poses danger to the environment ${ }^{(3)}$. Owing to lack of treatment, the wastewater containing dye residue consequently leads to several negative effects, including reduced light penetration, carcinogenicity, and mutagenicity ${ }^{(4)}$. However, the processing of textile wastewater is still rare and challenging especially when the pollutants are complex and recalcitrant.

In general, the textile industry's production can be performed by dry or wet process. During dry process in textile industry, water is required only as an auxiliary material instead of process medium. The dry process in textile industry includes spinning, weaving, knitting, and garment making. On the other hand, the wet process heavily uses water for both of as the process medium and as the main auxiliary material.

Wastewater with large quantity of dye contents must be treated prior to discharge into the water stream to keep environments healthy(5,6). Widely used dyes are synthetic substances having complex organic molecules. These dyes are relatively difficult to degrade due to their high solubility and complex aromatic molecular structures ${ }^{(7,8)}$. Various technologies have been employed for treating dye containing wastewater including reverse osmosis, coagulation, membrane filtration methods, ozonation process, chemical oxidation, and biosorption. Among all methods, adsorption methods by various adsorbents such as bentonite, double layered hydroxides, ash, and several other carbons are considered efficient, well-known, easy, and cheap technology for removing dyes ${ }^{(9)}$. Adsorption can be carried out using activated carbon, either in granular or powder form. Due to pore structure and large surface zone, activated carbon is widely utilized in separation, dyes and pollutants removal from wastewater as well as catalyst supports ${ }^{(10,11)}$. Furthermore, chemical oxidation is needed to ensure the effective and achievable approach technology to remove dyes/ chemicals pollution in biological textile wastewater ${ }^{(12)}$.

\subsection{Aims of Study}

In several previous studies, activated carbon has been proven to be a good adsorbent for adsorbing dyes in wastewater. Therefore, this study aims to determine the removal of color contained in artificial RB5 textile wastewater by adsorption technique using activated carbon.

\section{MATERIALS AND METHODS}

\subsection{Preparation of adsorbent materials}

The raw activated carbon was purchased from Bandung, Indonesia. This research used activated carbons surface areas ranging from 300 to $2,000 \mathrm{~m}^{2} / \mathrm{g}$. The surface area of the activated carbon used in this study is $1,000 \mathrm{~m}^{2} / \mathrm{g}$. Firstly, the adsorbent in the granular form was crushed and sieved into millimeter sized granule particles. The size of the powder activated carbon medium used is 30 mesh or $0.6 \mathrm{~mm}$ The adsorbent was readily activated to enlarge pore structures and made it more activated. The activation process also aims to remove the impurities on the surface of the adsorbent. In this experiment, the raw activated carbon was placed in an aqueous solution of potassium permanganate $\left(\mathrm{KMnO}_{4}\right)$ for 24 hours and it was subsequently dried at $105^{\circ} \mathrm{C}$.

\subsection{Dyes}

Azo-Reactive Black-5 (RB-5) dye was obtained from Bratachem. In this research, artificial wastewater was prepared by dissolving the dye in distilled water to simulate the actual textile wastewater. Calibration curves of dye solutions at different concentrations were constructed and subjected to UV-Vis spectroscopic measurement at the range of infrared wavelength at 400-800 $\mathrm{nm}$. Furthermore, the wavelength of maximum absorbance would be used as the wavelength of detection to find the wavelength of maximum absorption.

\subsection{Experimental procedure and sampling analysis}

The physicochemical treatment in this study involved adsorption by powdered activated carbon in a batch operation. Textile wastewater containing different initial dye concentrations (5 $\mathrm{mg} / \mathrm{L}, 10 \mathrm{mg} / \mathrm{L}, 15 \mathrm{mg} / \mathrm{L}$, and $20 \mathrm{mg} / \mathrm{L})$ were operated. At the start of each experiment, a $2 \mathrm{~L}$ glass reactor was filled with $0.5 \mathrm{~L}$ of textile wastewater and then stirred at 100 rotations per minute (rpm). At regular intervals, $3-6 \mathrm{~mL}$ of solution was taken out at $5,10,15,30,45$, and 60 minutes and analyzed immediately with a spectrophotometer to determine the color concentration. Prior to UV analysis, the aliquot was filtered through a $0.45 \mu \mathrm{m}$ filter (Whatman 
filter papers, ashless diameter $125 \mathrm{~mm}$, CAT number 1440-125). This color measurement refers to the standard methods ${ }^{(13)}$.

\subsection{Adsorption isotherm model}

The adsorption isotherm was studied to determine the adsorbent performance in removing dyes in textile artificial wastewater ${ }^{(7)}$. The adsorption of a substance on the adsorbent surface depends on several factors and has a certain adsorption isotherm pattern. The adsorption isotherm shows the equilibrium relationship between the solution's concentration and the amount of adsorbate adsorbed at a constant temperature. The adsorption of molecules or ions on a solid's surface is generally limited to a single molecular layer (monolayer). Therefore, the adsorption process usually follows the Freundlich and Langmuir adsorption equations. Equation 1 and 2 represent Langmuir and Freundlich equation, respectively as follows ${ }^{(7)}$ :

$$
\begin{aligned}
& \ln \left(q_{e}\right)=\ln \left(K_{f}\right) \frac{1}{n} \ln \left(C_{e}\right) \\
& \frac{1}{q_{\theta}}=\frac{1}{K_{L} Q_{0} C_{e}}+\frac{1}{Q_{0}} \ldots \ldots \ldots \ldots \ldots \ldots \ldots
\end{aligned}
$$

where $\mathrm{q}_{\mathrm{e}}$ is the adsorbents $(\mathrm{mg} / \mathrm{g}), \mathrm{C}_{e}$ is the equilibrium concentration $(\mathrm{mg} / \mathrm{L}), Q_{0}$ is the adsorption constant related to adsorption, $\mathrm{KL}$ is the adsorption constant related to energy of adsorption, $\mathrm{K}_{\mathrm{f}}$ is the adsorption constant measuring the adsorption intensity, and $n$ notation is the adsorption constant measuring the adsorption intensity. Based on those equations, the result would be expressed by linear regression. Adsorption kinetics is an important key to model the adsorption parameters of the color in the adsorption. $1 / q_{\mathrm{e}}$ was plotted against $1 / C_{e}$ and $\ln C_{e}$ was plotted against In $q_{e}$ to fit Langmuir and Freundlich isotherm, respectively. The best fit of the models was expressed in terms of linear regression coefficients $\left(R^{2}\right)$.

\section{RESULT AND DISCUSSION}

\subsection{The determination of maximum wavelength}

The UV-Vis spectrophotometry showed the characteristic peaks of Azo-Reactive Black-5 (RB-5) at $595 \mathrm{~nm}$ wavelength given in Figure 1.

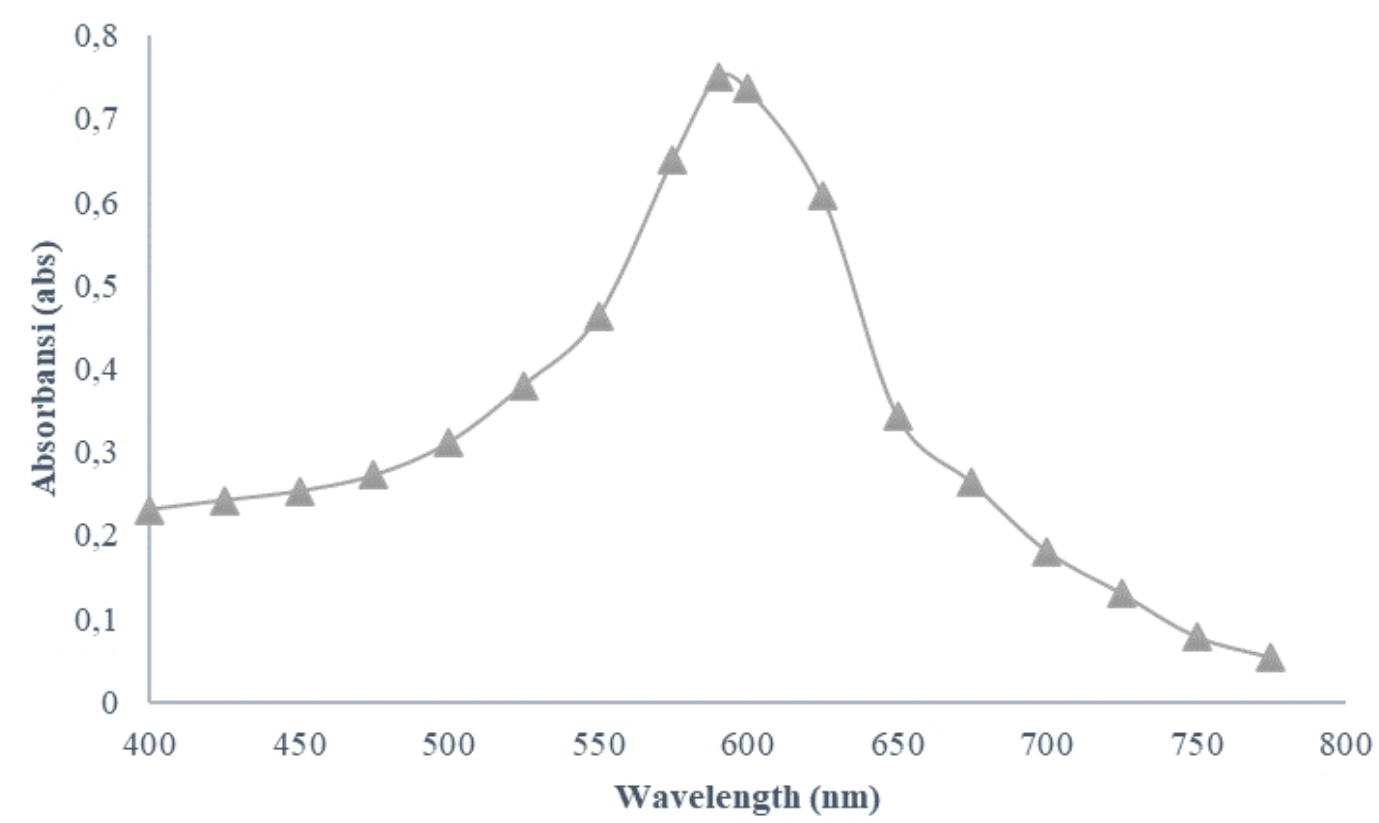

Figure 1. UV-Visible spectra of the textile wastewater (10 ppm of RB5)

3.2 Effect of different initial concentration and contact time on adsorption performance

Figure 2 compares the color reduction in textile wastewater for some initial concentration variation during the same treatment period. The efficiency of color removal decreased significantly after 60 minutes for all the different initial concentrations (data not shown). Figure 2 shows that the percentage of color removal increases with increase in contact time for all initial concentration variations. Maximum removal around $85 \% \mathrm{RB}$ was obtained at 60 minutes contact time for $5 \mathrm{mg} / \mathrm{L}, 10 \mathrm{mg} / \mathrm{L}$ and $15 \mathrm{mg} / \mathrm{L}$ of RB5 solutions. In contrast, powdered activated carbon removed $71.07 \%$ when initial concentration of RB5 was $20 \mathrm{mg} / \mathrm{L}$ at 60 minutes in contact time. These results revealed that color 
removal efficiencies remained largely unaffected by different initial dye concentration of $5 \mathrm{mg} / \mathrm{L}$ to $20 \mathrm{mg} / \mathrm{L}$. The reduction of textile wastewater's color content might be due to interaction between dye molecules with the available adsorption surface of powdered activated carbon resulting in a better color removal(14).

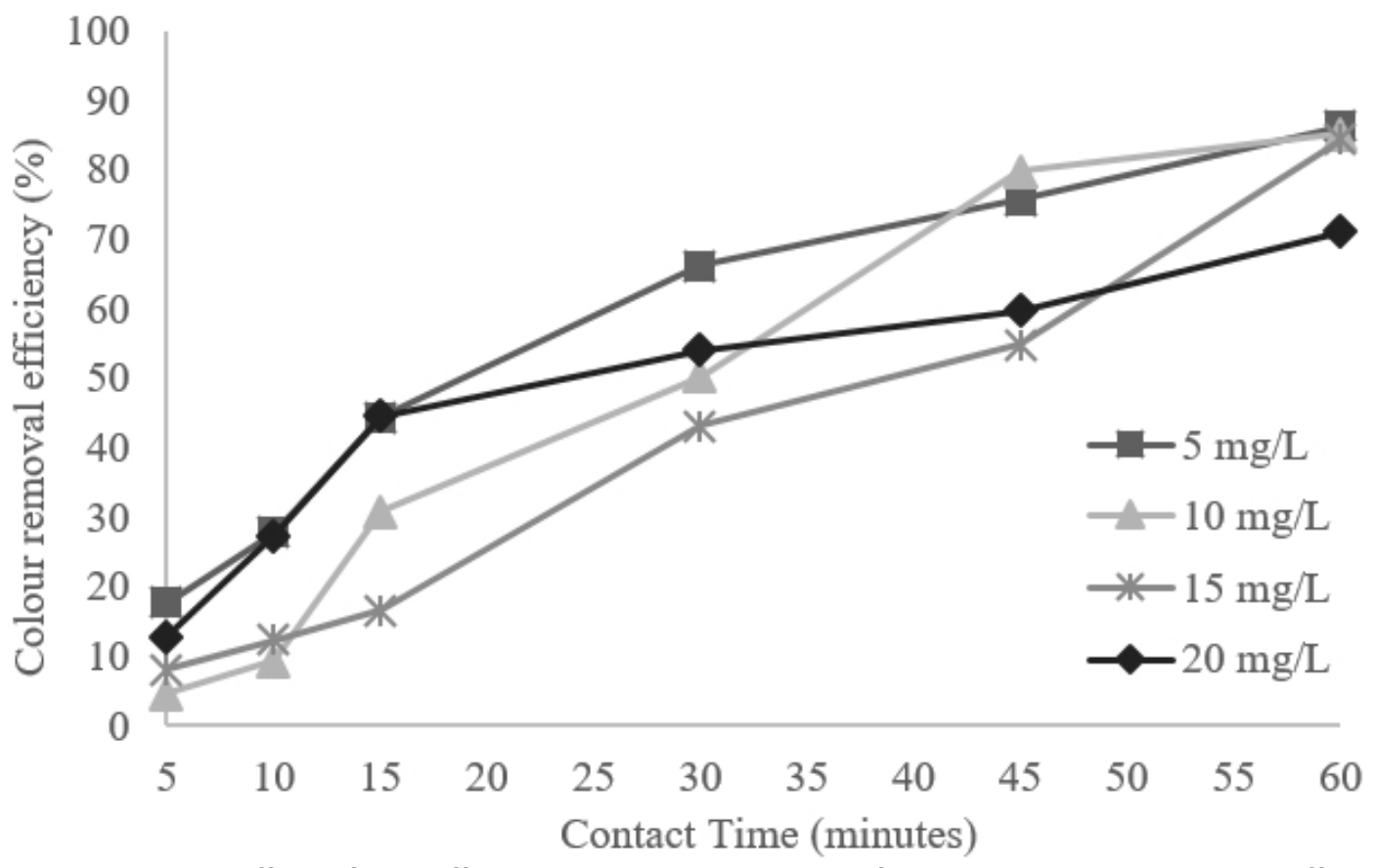

Figure 2. Effect of the different initial concentration of RB5 on the color removal efficiency

The effect of contact time on the percentage of color removal in the batch system was presented in Figure 2. It provides the percentage of color removal increases with increase in contact time for all initial concentrations. It was observed that the initial adsorption has had high rates. The adsorption rate rose gradually and showed a constant value after 60 minutes contact time due to the carbon surface's saturation with increasing contact time ${ }^{(15)}$.

\subsection{Adsorption Isotherm}

Isotherm study the interaction between the adsorbent and adsorbate to establish adsorption equilibrium ${ }^{(15)}$. Adsorption itself involves a concentration change event that occurs in the boundary plane between two phases because substances from one phase are attached to the other (occurs in surface). Adsorption can occur due to electrostatic attraction, hydrogen bonding or Van der Waals forces. Physical adsorption occurs when the adsorbate and the adsorbent surface bind only to Van der Waals(7). The adsorption isotherm can express the relationship between the amount of adsorbate adsorbed and the adsorbate concentration in solution at equilibrium and temperature. In this research, two isotherm models were used to determine isotherm in Table 1. The following table shows the initial measured dye concentrations, namely from $5.1 \mathrm{mg} / \mathrm{L}$ to $20.22 \mathrm{mg} / \mathrm{L}$ which is written in $\mathrm{C}_{0}$. The $\mathrm{C}_{\mathrm{e}}$ value shows the effluent concentration after the adsorption process, namely from $0.71 \mathrm{mg} / \mathrm{L}$ to $5.85 \mathrm{mg} / \mathrm{L}$, respectively. Removal efficiency shows the amount of dye removal that occurs at four different initial dye concentration. In this study, a removal efficiency of 70 to $87 \%$ were accomplished.

Table 1 Adsorption isotherm parameters for textile wastewater treatment at different initial dye concentration

\begin{tabular}{llcccccc}
\hline $\mathbf{C}_{\mathbf{0}}(\mathbf{m g} / \mathrm{L})$ & $\mathbf{C}_{\mathrm{e}}(\mathbf{m g} / \mathrm{L})$ & $\mathbf{q}_{\mathrm{e}}(\mathbf{m g} / \mathbf{g})$ & $\mathbf{1 / q _ { e }}$ & $\mathbf{1 / \mathbf { C } _ { e }}$ & Ln $\mathbf{q}_{\mathrm{e}}$ & Ln $\mathbf{C}_{\mathrm{e}}$ & Efficiency \\
\hline $\mathbf{5 . 1}$ & 0.71 & 0.44 & 2.26 & 1.41 & -0.81 & -0.34 & 86.21 \\
$\mathbf{1 0 . 3 9}$ & 1.54 & 0.89 & 1.13 & 0.65 & -0.12 & 0.43 & 85.21 \\
$\mathbf{1 5 . 4 2}$ & 2.42 & 1.30 & 0.77 & 0.41 & 0.26 & 0.88 & 84.29 \\
$\mathbf{2 0 . 2 2}$ & 5.85 & 1.44 & 0.70 & 0.17 & 0.36 & 1.77 & 71.07
\end{tabular}




\subsection{Adsorption Kinetics}

Adsorption kinetics describes the rate of solute/adsorbate for the adsorption process ${ }^{(7)}$. The results calculated for the two models are listed in Table 2. According to the coefficient of determination value of two models, the Langmuir isotherm model gave the better modelling approach for adsorption kinetics with determination coefficient $\left(\mathrm{r}^{2}\right)$ of 0.9756 than that of the Freundlich Isotherm model with $r^{2}$ of 0.8655 .

The Langmuir isotherm result is depicted in Figure 3. The maximum adsorption capacity of activated carbon (q) was equal to $4.353 \mathrm{mg} / \mathrm{g}$, and the Langmuir constants (b) was $0.312 \mathrm{mg} / \mathrm{L}$. Adsorption capacity presents the important index to evaluate the adsorption effect to adsorbents ${ }^{16)}$. On the other hand, the approaching model of Freundlich isotherm can be seen in Figure 4. The experiment results reveal that the value of $(1 / n)$ obtained is more than 1 , namely 1.538 for activated carbon. The $(1 / n)$ constant shows the favorability of the adsorption process. The range value of $0<1 / n<1$ indicates normal Langmuir isotherm where $1 / n>1$ indicates cooperative adsorption ${ }^{(7)}$. A value of (1/n) less than 1 implies that the adsorption following Freundlich isotherm is not limited to monolayer coverage but assumes heterogeneity of surface and multilayer $^{(7)}$. In addition, high adsorption capacity of activated carbon was gained as given by $\mathrm{K}_{\mathrm{f}}$ value of 2.234 tabulated in Table 2.

Table 2 Adsorption kinetic constants for adsorption of textile wastewater at a different initial dye concentration

\begin{tabular}{ccccc}
\hline \multicolumn{5}{c}{ Langmuir Isotherm } \\
\hline Adsorbent & Equation & $\mathrm{R}^{2}$ & $\mathrm{q}$ (unit) & $\mathrm{b}$ (unit) \\
Activated carbon & $\mathrm{y}=0.7346 \mathrm{x}-0.2297$ & 0.9756 & 4.3535 & 0.31269 \\
\hline \multicolumn{5}{c}{ Freundlich Isotherm } \\
\hline Adsorbent & Equation & $\mathrm{R}^{2}$ & $1 / \mathrm{n}$ (unit) & $\mathrm{K}_{\mathrm{f}}$ (unit) \\
Activated carbon & $\mathrm{y}=1.538 \mathrm{x}+0.8038$ & 0.8655 & 1.538 & 2.23401 \\
\hline
\end{tabular}

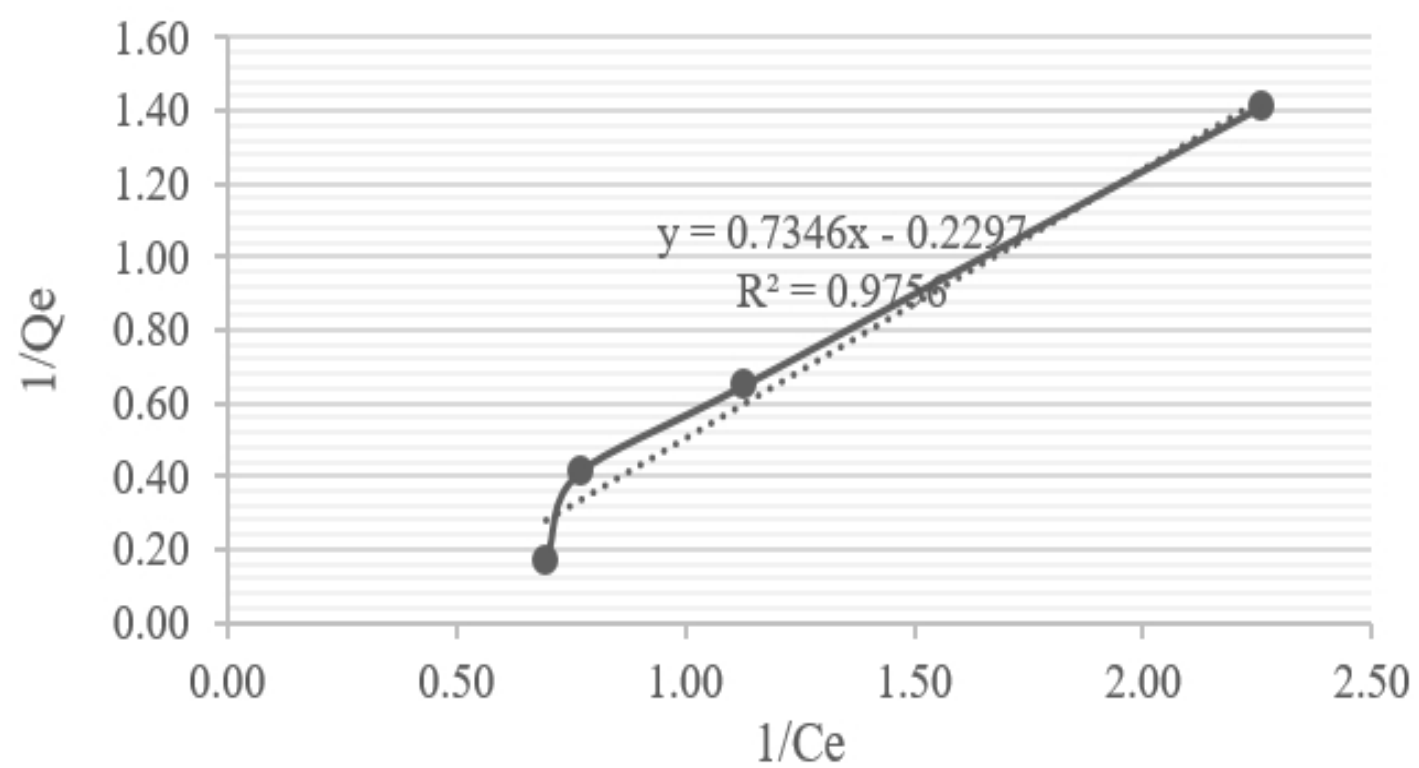

Figure 3. Langmuir adsorption isotherm model of textile wastewater by activated carbon 


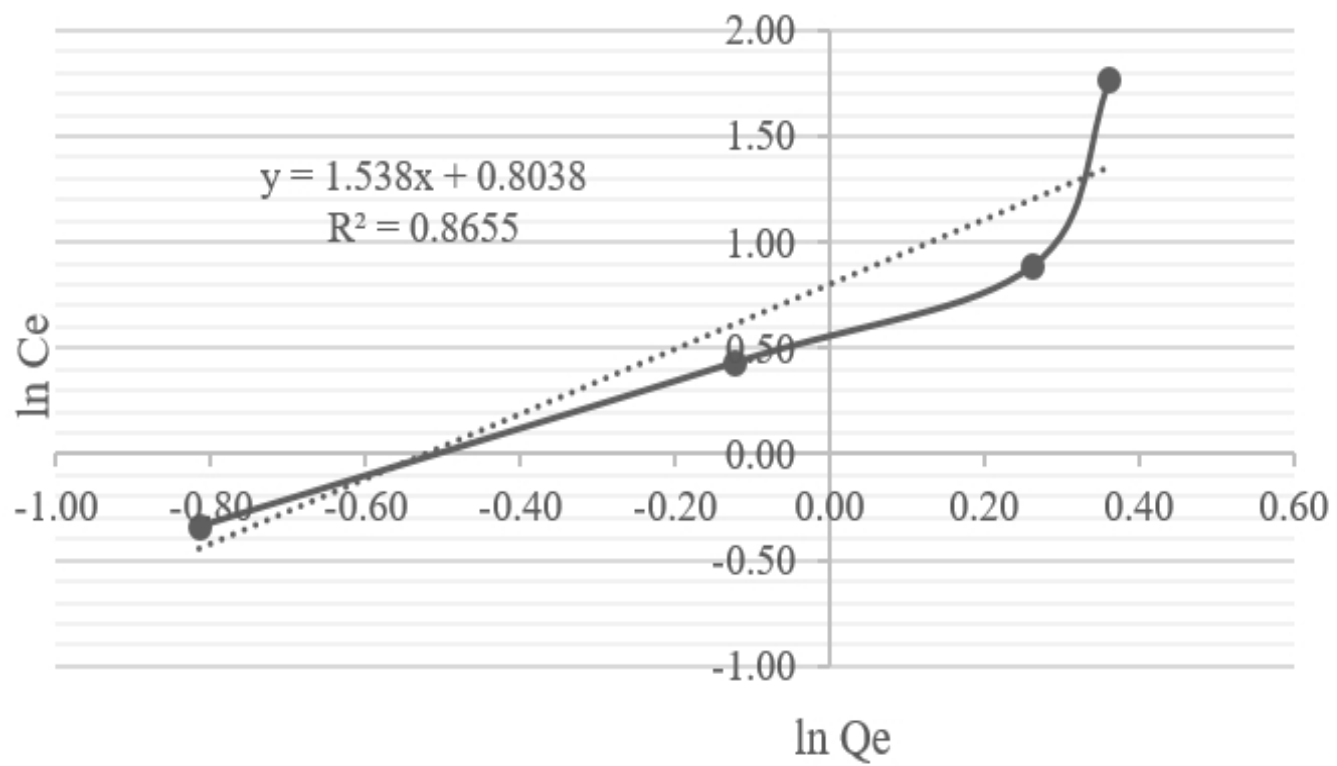

Figure 4. Freundlich adsorption isotherm model of textile wastewater by activated carbon

\section{CONCLUSIONS}

In this study, adsorption technology using powdered activated carbon was examined to treat textile wastewater for color removal at different initial dye concentration and adsorption contact time. It was observed that the adsorption proceeded initially with higher rates, gradually slowed down and finally attained a constant value due to the carbon surface's saturation with increasing contact time. At contact time of 60 minutes, the color removal by activated carbon in all reactors $(5 \mathrm{mg} / \mathrm{L}, 10 \mathrm{mg} / \mathrm{L}, 15 \mathrm{mg} / \mathrm{L}$, and 20 $\mathrm{mg} / \mathrm{L}$ of initial dye concentration variation) were $86.20 \%, \quad 85.21 \%, \quad 84.29 \%$, and $71.06 \%$ respectively. The highest color removal $(86.20 \%)$ could be achieved for 60 minutes of contact time with the initial dye concentration of $5 \mathrm{mg} / \mathrm{L}$. Langmuir adsorption isotherm showed the best fit with a maximum adsorption capacity of 4.353 $\mathrm{mg} / \mathrm{g}$.

\section{ACKNOWLEDGEMENT}

The authors would like to thank the laboratory staff who have assisted in the implementation of this research.

\section{REFERENCES}

1. Holkar, C.R., Jadhav, A.J, Pinjari. D.V, Mahamuni. N.M, \& Pandit. A.B. (2016) A critical review on textile wastewater treatments: Possible approaches, J. Environ. Manage. 182, 351-366.

2. Apritama, M., Suryawan, I., Afifah, A. S., \& Septiariva, I. Y. (2020). Phytoremediation of effluent textile wwtp for $\mathrm{NH} 3-\mathrm{N}$ and $\mathrm{Cu}$ reduction using pistia stratiotes. Plant Archives, 20 (Supplement 1), 2384-2388.

3. Kant, R. (2012) Textile dyeing industry an environmental hazard, Natural Science. 4, 2226.

4. Ghaedi, M, Nasab, A.G, Khodadoust, S, Sahraei, R, \& Daneshfar, A. (2015) Characterization of zinc oxide nanorods loaded on activated carbon as cheao and efficient adsorbent for removal of methylene blue, J. Ind. Eng. Chem, 21, 986-993.

5. Suryawan, I. W. K., Prajati, G., Afifah, A. S., \& Apritama, M. R. (2020). $\mathrm{NH}_{3}-\mathrm{N}$ and COD reduction in Endek (Balinese textile) wastewater by activated sludge under different DO condition with ozone pretreatment. Walailak Journal of Science and Technology (WJST).

6. Suryawan, I. W. K., Helmy, Q., \& Notodarmojo, S. (2020) Laboratory scale ozone-based post-treatment from textile wastewater treatment plant effluent for water reuse. Journal of Physics: Conference Series, 1456, 1-7.

7. Cheng, S, Zhang. L, Ma. Aiyuan, Xia. Hongying, Peng. Jinhui, Li. Chunyang, Shu. \& Jianhua. (2017) Comparison of activated carbon and iron/cerium modified activated carbon to remove methylene blue from wastewater, Journal of Sciences. 65. 10.1016/j.jes.2016.12.027.

8. Suryawan, I. W., Helmy, Q., \& Notodarmojo, S. (2018) Textile wastewater treatment: 
colour and COD removal of Reactive Black- 5 by ozonation. IOP Conf. Series: Earth and Environmental Science, 106, 1-6

9. Mu'azu, N.D, Jarrah. N, Kazeem. T.S, Zubair. M, \& Al-Harthi. M. (2018) Bentonite-layered double hydroxide composite for enhanced aqueous adsorption of Eriochrome Black $\mathrm{T}$, Applied Clay Science. 161, 23-24.

10. Paska, O. M, Pacurariu. C, \& Muntean. S.G. (2014) Kinetic and thermodynamic studies on methylene blue biosorption using corn-husk, RSC Advances 4. 107, 626261-6230.

11. Ge, X.Y, Wu, Z.S, Wu, Z.I, Yan. Y.J, Cravotto, G, Ye. B.C. (2016) Enhanced PAHs adsorption using iron-modified coal-based activated carbon via microwave radiation, J. Taiwan Inst. Vhem. Eng. 64, 235-243.

12. Suryawan, I. W., Siregar, M. J., Prajati, G., \& Afifah, A. S. (2019) Integrated Ozone and Anoxic-Aerobic Activated Sludge Reactor for
Endek (Balinese Textile) Wastewater Treatment. Journal of Ecological Engineering, 20(7).

13. APHA. (1995) Standard Methods for Examination Water and Wastewater $3464 \mathrm{p}$ (American Public Health.

14. Khan, T.A, \& Dahiya. S.I. (2012) Removal of direct red 81 dye from aqueous solution by native and citric acid modified bamboo sawdust-kinetic study and equilibrium isotherm analyses, J. Sci. 25, 59-87.

15. Sharma, A, Syed. Z, Brighu. U, Gupta. A.B., \& Ram. C. (2019) Adsorption of textile wastewater on alkali-activated carbon, Journal of Cleaner Production).

16. Kuang, Y., Zhang, X., \& Zhou, S. (2020) Adsorption of Methylene Blue in Water onto Activated Carbon by Surfactant Modification, Water, 12, 587. 